\title{
Cytomorphological and Sterility Studies in Digitaria polevansii Stent
}

\author{
K. G. Shambulingappa $a^{1}$ \\ INTRODUCTION
}

In the course of cytological investigations of several accessions of Digitaria, a plant that was highly pollen-sterile was encountered. This plant bearing the USDA No. 299782 was found to be Digitaria polevansii Stent. Digitaria polevansii is a stoloniferous perennial and has fine stems. According to Chippindall (8), ${ }^{2}$ Digitaria polevansii resembles in many respects the robust form of $D$. pentzii, but differs with respect to rhizome formation and culm bases. The rhizome is thick, knotty, much branched, and woody. The straight culms are up to $120 \mathrm{~cm}$. high, the leaves almost glabrous, blades up to $40 \mathrm{~cm}$. long and $11 \mathrm{~mm}$. wide; ligule up to $3 \mathrm{~mm}$. long; racemes 9 to 17 cm. long, 4 to 12 arranged digitately or on a short central axis; spikelets 3 to $3.5 \mathrm{~mm}$. long, fairly conspicuously hairy. The material was originally introduced as stolons from Rietondale Research Station by Oakes ( 9 ).

Chromosome number and cytology of this species have not been reported previously. The present paper reports the chromosome number of this species, and also detailed studies of meiotic irregularities which are responsible for the high percentage of pollen sterility that has been recorded in this plant.

\section{MATERIAL AND METHODS}

The material under consideration was introduced from Beltsville, $M d$. as living plants on June 15, 1964, and has been maintained in a clay pot, to serve as a source of vegetative material for cytological and agronomic studies.

Panicles for meiotic studies were fixed in 3 parts of alcohol and 1 part of propionic acid, the latter having been previously saturated with ferric acetate (17) for 24 hours or more.

Anthers taken directly from the fixative were used to make smear preparations. Analysis of different meiotic stages were made with a Leitz microscope fitted with phase contrast. Photographs were taken from the fresh slides using a green filter. Pollen studies were carried out by staining them with equal amounts of 1-percent acetocarmine and glycerol.

1 Associate Cytogeneticist, Agricultural Experiment Station, Mayagüez Campus, University of Puerto Rico, Río Piedras, P.R.

2 Italic numbers in parentheses refer to Literature Cited, pp. 111-2. 


\section{OBSERVATIONS}

Preliminary examination of the pollen revealed about 85 to 90 percent sterility. Chromosome number of this accession was determined by analyzing the pollen mother cells that appeared to have normal diakinesis and metaphase I and anaphase I. Such studies revealed that the somatic chromosome number of this species was $2 n=36$, and formed mostly 18 normal bivalents at diakinesis and metaphase $\mathrm{I}$.

Meiosis, in general, was abnormal at all stages. At pachytene, abnormalities such as loose pairing, crumpling of chromatin material into 3 or 4 groups followed by their gradual disintegration were observed (figs. 1 and 2). Rarely, however, cells with normal pachytene stage were encountered (fig. 3), and analysis of pachytene chromosomes in these cells showed that they contained two different types of chromosomes: 1, Pachytene chromosomes in which the position of the centromere could be located and; 2, pachytene chromosomes in which the centromeric position could not be located.

At diplotene the bivalents showed a great deal of stickiness. Some of them appeared like small condensed bodies, as if they were at diakinesis of the metaphase I stage, while others still exhibited long threadlike structures indicating differential condensation and spiralization (fig. 4). Three to four nuclear bodies were generally found at this stage.

Pollen cells with regular 18 bivalents, or 16 bivalents and 1 quadrivalent, were rarely encountered at diakinesis (fig. 5). Univalents ranging from 6 to 30 were seen in about 25 percent of the PMCs (fig. 6). The rest of the diakineticlike-appearing cells showed scattered chromatin material all over the cell. Metaphase I was characterized by diffused chromatin bodies on the equatorial line, or a mass of chromatin material at the center and small chromatin bodies scattered around (figs. 7 and 8). Occasionally, however, cells were observed (fig. 9) with normal metaphase $I$ in about 2 to 3 percent of them showing 18 bivalents.

Vely few cells reaching the anaphase I stage were noted. The types of abnormalities that were generally met with at this stage were lagging chromosomes, chromatin bridges, and restitution nuclei. About 2 to 3 percent of the cells showed normal anaphasic separation of 18/18. Cell-wall formation after the first division of meiosis, which is a regular phenomenon in the Gramineae, did not take place in this material. As a result, cells containing two nuclei were mostly seen (fig. 10) and these, apparently, did not enter the second meiotic division. In a very few cells anaphase II and metaphase II stages were seen, and even they were highly abnormal (fig. 11). Examination of fully developed anthers for pollen sterility exhibited cells with one to four nuclei in addition to micronuclei (fig. 12). No seeds were recovered from the plant. 


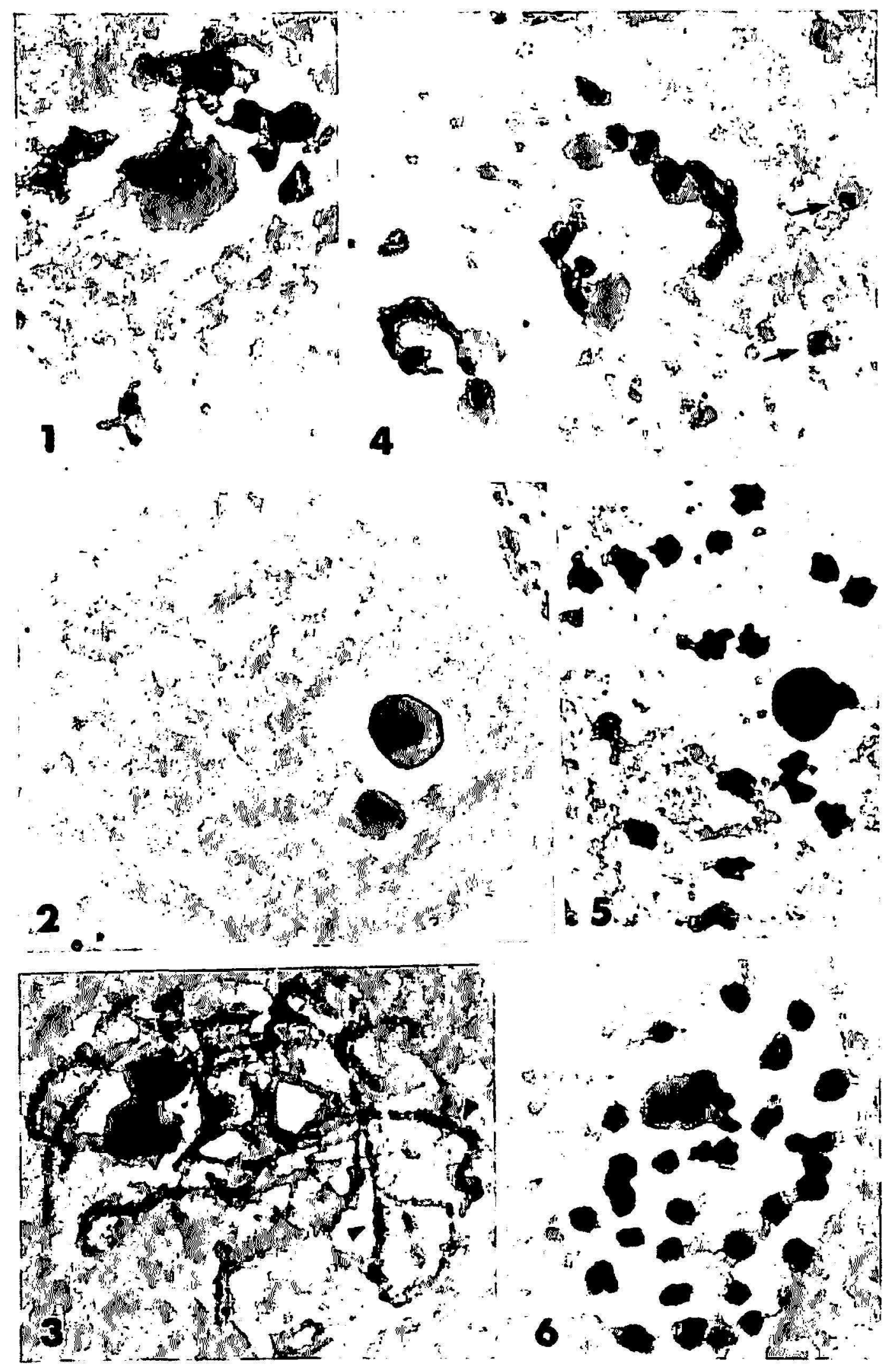

lisi. 1.-Pachytene stage showing crumpling and breakdown of chromatin matorial $(\times 1,200)$.

FI(i, 2.-- 1)isint egrat ion of chromatin material $(\times 1,200)$.

Fici. 3- PMC showing more or less normal pachytene chromosomes (Arrows indicate the position of cent romere $)(\times 1,200)$.

Fig. 4.-Pollen mother cell at diplotene-note the highly condensed chromosomes $(\nearrow)$ as compared to the others $(\times 1,200)$.

FIti. 5.--Diakinesis showing $16_{11}+I_{I X}(\times 1,200)$.

Fıc. (j.--1)iakinesis showing $3_{I}+30_{1}(\times 1,200)$. 


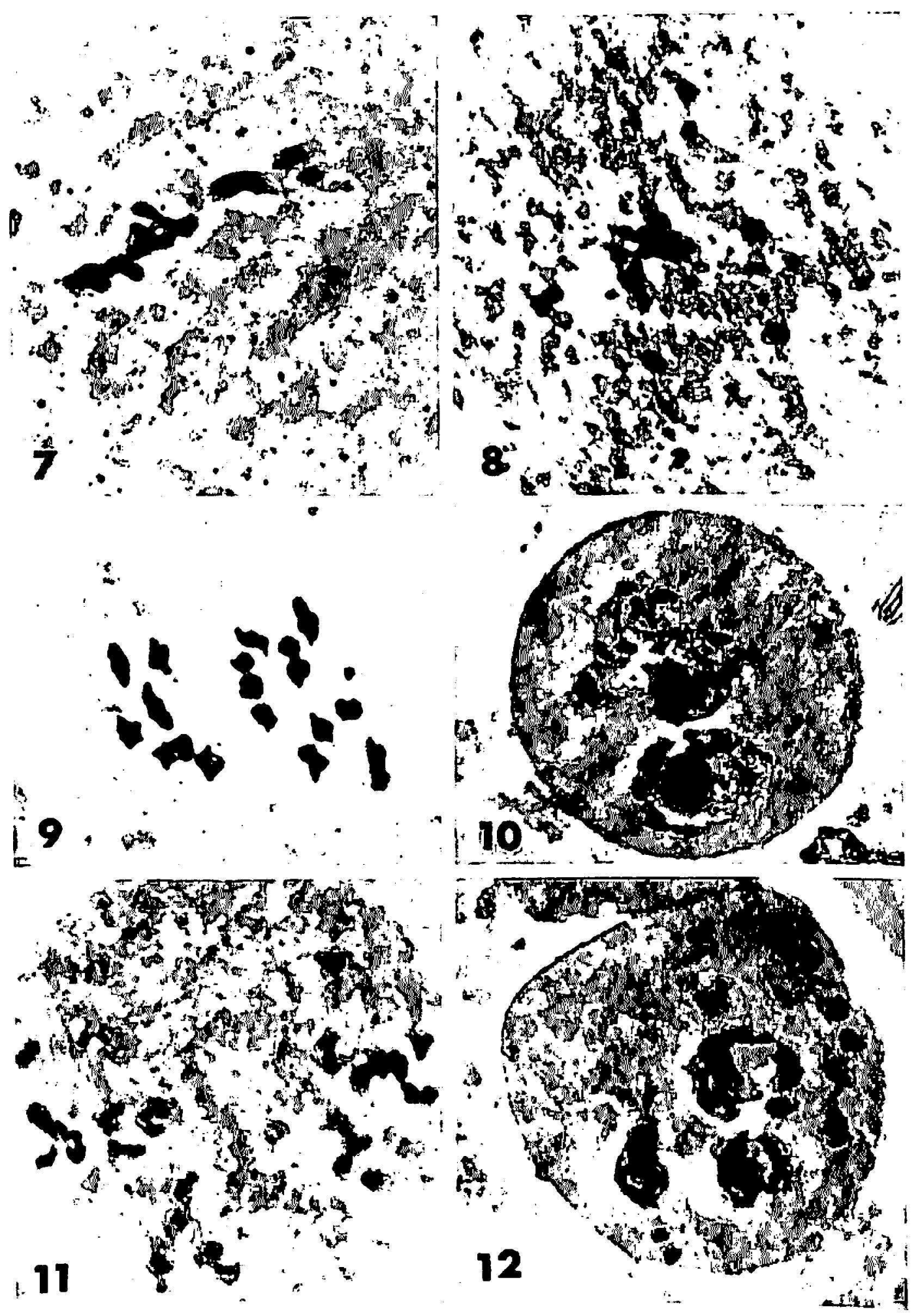

FIci. T.-Metaphase I, partly disintegrated chromosomes lying on the equatorial plate $(\times 1,200)$.

Fig. 8.-Metaphase $I$, a mass of chromosomes at the center and others scattered over the cytoplasm $(\times 1,200)$.

Fs(i. 9.-A normal metaphase I plate with $18_{11}(\times 1,200)$.

Fiti. 10.-A binucleate cell without cell-wall formation $(X 1,200)$.

Frri. 11.-Metaphase II showing scattered chromosomes $(X 1,200)$.

Fur. 12.-PMC showing 3 big unclei and 6 micronuclei $(\times 1,200)$. 


\section{DISCUSSION}

Most of the cytological investigations in the genus Digitaria have been confined to reporting the chromosome numbers of several species. However, Virkki and Purcell (19) studied meiosis in detail in several accessions of $D$. valida and reported mostly normal behaviour of chromosomes. The only known case of sterility is that reported by Sheth et al. (16) in D. decumbens. The cause of sterility in this case was mostly the aneuploid nature $(2 n=$ 30 ) of the material. Most of the diploid, tetraploid, and hexaploid types of Digitarias so far examined (author's' unpublished data) appeared to exhibit normal meiosis with mostly bivalent formation.

Shambulingappa (14) has reported four types of morphologically distinct pachytene chromosomes in six species of Digitaria. He also presumes that probably a few more types of pachytene chromosomes might exist. Furthermore, he has suggested the possible use of this information in determining the nature of ploidy and to some extent, if possible, through extrapolation, in the identification of parental diploid species that have contributed to the origin of tetraploids and hexaploids. Analysis of pachytene chromosomes in a few analysable cells in $D$. polevansii has revealed that this species contains two morphologically distinct types of chromosomes. In addition, analyses of chromosome configurations at diakinesis and metaphase in PMCs that were apparently normal have revealed mostly bivalents. It may, therefore, be conceived that $D$. polevansii is an amphidiploid which has arisen as a result of hybridization between two different species with $2 n=18$ followed by chromosome doubling in the $F_{1}$.

Cases of sterility accompanied by meiotic irregularities have been reported in several crop plants $(4,5,12,15)$. The causes of meiotic irregularities may be one or more: chromosomal imbalance, new polyploidization, hybridization, desynapsis, or asynapsis. In the present material there are only two possibilities for meiotic irregularities viz., 1, either recent polyploidization or 2, desynapsis. It is indeed difficult to know how recently this polyploid species has originated. Nevertheless, Stent (17) reported this species as one of the new Digitaria species.

The desynaptic phenomenon has been observed in several crop plants $(7,8,10,11)$. In several cases the condition of desynapsis is genetically controlled $(1,2,6)$. Prakken (11) classified desynaptics into three groups on the basis of the degree of failure in pairing of the chromosomes: 1 , Weak, which includes those chromosomes that are slightly different from the normal ones; 2, medium-strong, which includes those that show a certain amount of pairing at pachytene and bivalents at diakinesis and at metaphase I; and 3 , strong, which includes those showing very little pairing and apparently no bivalents at diakinesis and metaphase I. The observations made of the present material clearly indicate that the desynaptic phenomenon is of the 
medium-strong type. Furthermore, in addition to the desynaptic phenomenon it appears that there is some physiological imbalance which may be the cause of disintegration of chromatin material and failure to form the cell wall.

\section{SUMMARY}

Detailed meiotic studies carried out in $D$. polevansii which was found to be highly pollen-sterile revealed that it has a somatic chromosome number of $2 n=36$. This is the first report on the cytology and chromosome number of this species. Analysis of pachytene chromosomes has shown that this species contains two different types of chromosomes. In a few cells that were normal, bivalents were mostly observed at diakinesis and metaphase I. Information obtained through the analysis of chromosomes at pachytene, diakinesis, and metaphase I clearly indicates that $D$. polevansi $i$ is an allopolyploid.

Several meiotic irregularities that are characteristic of desynaptics are reported. In addition to the desynaptic phenomenon it is also suggested that there might be some type of physiological imbalance causing disintegration of chromatin material and failure to form the cell wall.

\section{RESUMEN}

Los detallados estudios meíticos que se realizaron con $D$. polevansii, cuyo polen es muy estéril, revelaron que su número de cromosomas somáticos es $2 n=36$. Este es el primer informe que se conoce sobre la citología y el número de cromosomas de esta especie. Un análisis de los cromosomas del estadio paquiténico ha demostrado que esta especie contiene dos tipos distintos de cromosomas. En algunas células normales, se observaron bivalentes mayormente durante la diacinesis y la metafase I. La información que se obtuvo mediante un análisis de los cromosomas durante el estadio paquiténico, la diacinesis y la metafase I indica claramente que $D$. polevansii es un alopoliploide.

Se informan varias irregularidades meióticas que son típicas de los desinápticos. Además del fenómeno desináptico, también se sugiere la posibilidad de que exista algún tipo de imbalance fisiológico que cause la desintegración de la cromatina y no permita la formación de la pared celular.

\section{LITERATURE CITED}

1. Beadle, G. W., Genetical and cytological studies of Mendelian asynapsis in Zea mays, Mem. Cornell Agric. Exp. Sta. 12: 1-23, 1930.

2. Celarier, R. P., Desynapsis in Tradescantia, Cytologia 20: 69-83, 1955.

3. Chippindall, L. K. A., A guide to the identification of grasses in South Africa, in The Grasses and Pastures of South Africa, published by Central News Agency,
pp. 414, 1959. 
4. Groff, D. and Bremis, W. P., Meiotic irregularities in Cucurbita species hybrids, J. Hered. 68: 109-11, 1967.

5. Hadley, H. H. and Starnes, W. J., Sterility in soybeans caused by asynapsis, Crop Sci. 4: 421-4, 1964.

6. Johnson, H., Meiotic aberrations and sterility in Alopecurus myosuroides Huds., Hereditas 80: 469-566, 1966.

7. Li, H. W., Pao, W. K., and Li, C. L., Desynapsis in the common wheat, Amer. J. Bot. 82: 92-101, 1945.

8. Magoon, M. L., Ramanna, M. S., and Shambulingappa, K. G., Desynapsis and spontaneous chromosome breakage in Sorghum purpureo-seroceum, Indian $J$. Genet. 21: 87-97, 1861.

9. Oakes, A. J., Plant Exploration in South Africa, USDA publication, pp. 84, 1964.

10. Pal, B. P. and Ramanujam, S., Asynapsis in Chillies (Capsicum annurm), Curr. Sci. 8: 126-8, 1940.

11. Prakken, R., Studies of asynapsis in rye, Hereditas 29: 475-95, 1943.

12. Shambulingappa, K. G., Meiotic abnormalities in Nicotiana glutinosa, Genelica Iberica, 18: 157-66, 1966.

13. - Cytomorphological studies of Clematis hatherliensis (C. orientalis $\mathrm{x} . C$. tangutica), Caryologia 19: 395-401, 1966.

14. - Studies on the pachytene chromosomes in the genus Digitaria, Genetica (Nether.) 88: 381-7, 1967.

15. Shambulingappa, K. G. and Magoon, M. L., Cytomorphological studies in the genus Sorghum, Indian J. Genet. 28: 275-89, 1963.

16. Sheth, A., Yu, L., and Edwardson, J., Sterility in pangola grass, Digitaria decumbens Stent, Agron. J. 48: 505-7, 1956.

17. Stent, S. M., South African Gramineae. Some new species of Digitaria, Bothalia Nat. Herbarium, Union of South Africa, s: 149, 1930.

18. Swaminathan, M. S., Magoon, M. L., and Mehra, K. L., A simple propionocarmine PMC smear method for plants with small chromosomes, Indian J. Genet. 14: 87-8, 1954.

19. Virkii, N. and Purcell, C. M., Observations on the behavior, genetics, and cytology of two South African Digitaria valida Stent accessions in Puerto Rico, J. Agri. Univ. P.R. 51 (4): 269-85, 1967. 